\title{
Analysis of Adoption of Improved Groundnut Varieties in the Tropical Legume Project (TL III) States in Nigeria
}

\author{
Benjamin Ahmed1, Candidus Alichenu Echekwu2', S. G. Mohammed ${ }^{3}$, Chris 0jiewo4, \\ Hakeem Ajeigbe ${ }^{5}$, Micheal Bobboh Vabi ${ }^{5}$, Hippolyte Affognon ${ }^{6}$, Jourdain Lokossou ${ }^{6}$, \\ Ogechi Cordelia Nwahia ${ }^{1}$
}

\author{
${ }^{1}$ Department of Agricultural Economics, Institute for Agricultural Research (IAR), Ahmadu Bello University, Zaria, Nigeria \\ ${ }^{2}$ Department of Plant Science, Institute for Agricultural Research (IAR), Ahmadu, Bello University, Zaria, Nigeria \\ ${ }^{3}$ Center for Dryland Agriculture, Bayero University, Kano, Nigeria \\ ${ }^{4}$ International Crop Research Institute for the Semi-Arid Tropics (ICRISAT), East African Regional Office, Nairobi, Kenya \\ ${ }^{5}$ International Crop Research Institute for the Semi-Arid Tropics (ICRISAT), Kano, Nigeria \\ ${ }^{6}$ International Crop Research Institute for Semi-Arid Tropics (ICRISAT), Bamako, Mali \\ Email: ahmedben33@gmail.com, candidusechekwu@gmail.com, sanusi.gaya@buk.edu.ng,c.ojiewo@cgiar.org, \\ h.ajeigbe@cgiar.org,1.jourdain@icrisat.org,M.Vabi@cgiar.org,godstime_ogefine@yahoo.com
}

How to cite this paper: Ahmed, B., Echekwu, C.A., Mohammed, S.G., Ojiewo, C., Ajeigbe, H., Vabi, M.B., Affognon, H., Lokossou, J. and Nwahia, O.C. (2020) Analysis of Adoption of Improved Groundnut Varieties in the Tropical Legume Project (TL III) States in Nigeria. Agricultural Sciences, 11, 143-156.

https://doi.org/10.4236/as.2020.112009

Received: December 2, 2019

Accepted: February 14, 2020

Published: February 17, 2020

Copyright ( 2020 by author(s) and Scientific Research Publishing Inc. This work is licensed under the Creative Commons Attribution International License (CC BY 4.0).

http://creativecommons.org/licenses/by/4.0/ (c) (i) Open Access

\begin{abstract}
Agricultural technologies and innovations play a great role in increasing productivity, alleviating and reducing poverty and contributing to economic development and this is made possible through adoption of improved technologies and innovations. This study centered on analysis of adoption of improved groundnut varieties in the Tropical Legume (TL III) States of Nigeria. Purposive and simple random sampling techniques were used to select 1476 groundnut farmers in the project States and from whom primary data were collected using electronic data capturing instrument containing the questionnaire. The data were analyzed using descriptive statistics and Average Treatment Effect (ATE) framework. The results showed that the breeding and promotion of improved groundnut varieties in Nigeria under the Tropical Legume Project and with the synergy of USAID groundnut up-scaling Project in Nigeria resulted in very high level of awareness of improved varieties, more than average level of access to the improved variety seeds, moderate level of utilization of the improved varieties among the groundnut farmers and the adoption rate of improved varieties increased from $8 \%$ at based line to $57 \%$ at the end of the project. The study recommends extension of the project to facilitate further access to these varieties and for state governments to take ownership of the projects in terms of financial commitments to promotional efforts for mass adoption by farmers.
\end{abstract}




\section{Keywords}

Adoption, Improved Groundnut Varieties, Tropical Legume (TL III) Project

\section{Introduction}

Groundnuts (Arachis hypogaea L.), known as peanuts, earthnut or monkey nuts and groundnut is edible crop which can be eaten raw or processed into oil, cake or snack foods. It is a legume plant that is cultivated throughout the tropical, sub-tropical and the warm temperate climatic zones [1] in nearly 100 countries, of which over $90 \%$ are developing countries on nearly 24.6 million hectares of land, with a production of 41.3 metric tons and productivity of $1676 \mathrm{~kg} / \mathrm{ha}$ [2]. Groundnut is a staple food and valuable cash crop for millions of households [3]. The "nuts" are high in oil content (between $40 \%$ - 50\%) and protein content (between $25 \%-32 \%$ ), and also a good source of essential vitamins and minerals [4]. Groundnut improves soil fertility through nitrogen fixation, thereby increasing the productivity of other crops when used in rotation or in a cereal cropping system. It was estimated that on average, groundnut contributes to about $60 \mathrm{~kg}$ nitrogen per hectare. However, China, India, Nigeria, the USA and Myanmar are the leading groundnut producing countries in the world. Nigeria is the largest groundnut producing country in West Africa, accounting for $51 \%$ of production in the region and contributing about $10 \%$ of total global production and $39 \%$ to that of Africa [1]. Nigerian groundnut production has been increasing at a growth rate of $8 \%$ per annual resulting from area expansion of $6 \%$ and increased productivity of $2 \%$ [5].

Nigerian groundnut farmers for many decades relied solely on the local varieties which have affected productivity greatly because of its limitations of low yield, low resistance to disease and long maturity period [1].

The Tropical Legume (TL) project was implemented by three international Centres (International Centre for Tropical Agriculture (CIAT), International Institute for Tropical Agriculture (IITA) and the International Crop Research Institute for the Semi-Arid Tropics (ICRISAT)) of the Consultative Group on International Agricultural Research (CGIAR) and in Partnership with 15 National Agricultural Research Institutes (NARIs) in Sub-Saharan Africa (SSA) and South East Asia (SA). The Project was in three phases-TL1 from 2007-2011; TL II from 2012-2014 and TL III from 2015-2019. The aim of the project was to improve the livelihoods of small holder farmers through improved productivity and production of major grain legume crops-chickpea, common beans, groundnut, cowpea, pigeon pea and soybean in the drought prone sub-Saharan Africa and South East Asia. Nigeria is among the West African countries that benefitted from the project in all the phases and the crops involved were cowpea and groundnut. The groundnut project was implemented in five (Bauchi, Jigawa, 
Kano, Katsina and Kebbi) of the 37 States including the Federal Capital Territory (FCT) in the country all located across the Northern Guinea Savanna (NGS), Sudan Savanna (SS) and Sahel Savanna (Sahel) where the soil and climate are most favourable to commercial production in Nigeria and not production commercial in Nigeria. Figure 1 shows the ecology and project states. Since 2007 about 101 groundnut varieties were developed and released and 110,695 tons of certified seed were produced and planted on about 1.11 million ha by 2018 [6]. Under TL III, six new varieties with end-user preferred traits were released to replace some of the old varieties that are no longer meeting end-users' demands

The TL III Project emphasized breeder foundation seed production and improved variety dissemination and adoption. To facilitate this process, the groundnut up-scaling project and groundnut seed systems were introduced as complementary projects to the continued improved variety development.

Thus, in order to assess the progress made in disseminating the improved varieties across the project States in Nigeria, Objective one of TL III Project was given the mandate to conduct this study with the sole objective of determining the adoption level and impact of the varieties released and promoted from TL II Project. These improved varieties have been disseminated to the farmers and

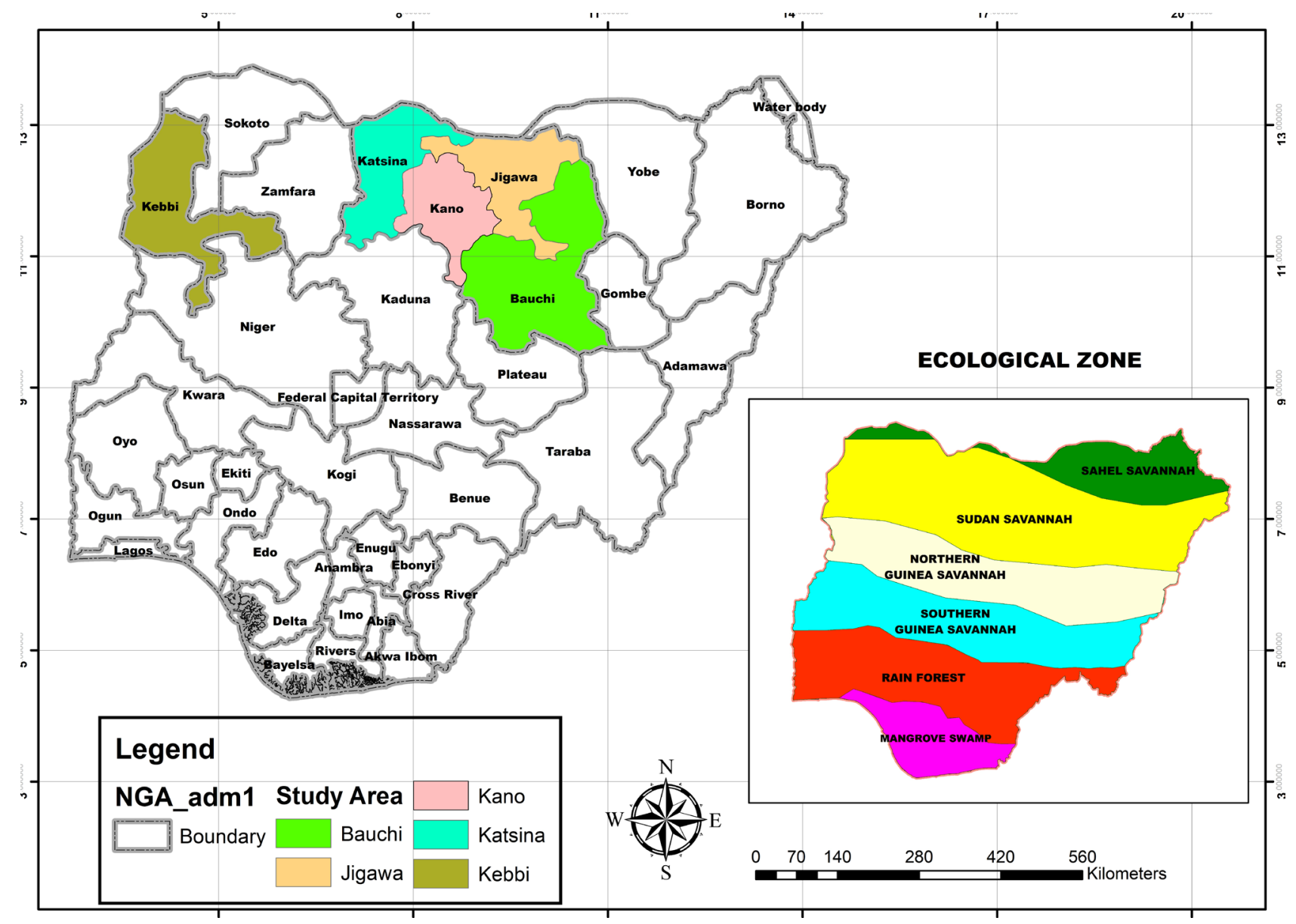

Figure 1. Map of Nigeria showing the ecological zones and the tropical legume project states. 
adoptions were observed. However, empirical information concerning the rate of the adoption of these improved varieties is not known. Few studies on improved groundnut varieties have centered on the intensity of adoption or the determinants of adoption using Tobit, Logit or Probit models, but this study made use of Average Treatment Effect (ATE) framework to determine the rate of the adoption of these improved varieties. After the many years of Tropical Legume Project operation in Nigeria (TL II Started in 2007), the assessment of the project in terms of adoption rate of these improved groundnut varieties become pertinent and the foregoing questions become imperative. What are the socio-economic characteristics of the adopters; and to what extent has the project achieved its target with respect to the adoption of the promoted improved varieties by the farmers?

\section{Empirical Framework}

Improved groundnut varieties have been disseminated to the farmers, the International Crops Research Institute for the Semi-Arid Tropics (ICRISAT), believed that the adoption of these improved groundnut varieties will contribute significantly to reducing poverty, increasing food security, improved health, enhanced sustainability of natural resource base of adopters, but as reported in literature most of the constraints to adoption of new innovations includes extreme weather, liquidity constraints, and lack of awareness of technologies [7] which implies that awareness is an important precondition for adoption to occur. In many occasions, exposure to a technology is not random. Individuals are usually exposed to new technologies because they are targeted by the researchers or extension workers based on the prejudice of their higher probability of adoption and some farmers through their individual effort get exposed to the new technology. When the entire population is not exposed to the new technology, the observed sample adoption rate is not a consistent estimator of the true population adoption rate because of "non-exposure and selection bias" [7]. Because of the non-exposure and selection biases, the causal effects of determinants of adoption cannot be consistently estimated using classical adoption models such as probit, logit and tobit. Thus, this research analysis is based on Average Treatment Effect (ATE) framework of technology adoption under partial population exposure proposed by Diagne and Demont [7]. Some groundnut farming population is not aware of the existence of improved groundnut varieties years after it was introduced, therefore, applying the average treatment framework allows us to control for non-exposure and selection biases and helps in estimating true population adoption rates. The treatment variable adopted in this study is "awareness and access" to at least one variety of improved groundnut variety such that those exposed and have access to the improved groundnut varieties are considered as "treated", while those unaware and does not have access are considered as "untreated".

Following Woodridge [8] and Diagne and Demont [7], let's consider $y 1$ as the 
potential adoption outcome when exposed and have access to improved groundnut varieties and $y 0$ as the potential adoption outcome when exposure and access is not there. Hence the expected population adoption to the new varieties is given by $E(y 1-y 0)$. Since awareness and access is a precondition for adoption to occur, we have $y 1=1$ and $y 0=0$ for all farmers exposed and have access and those farmers that were not exposed and does not have access respectively. Hence the adoption of the ith farmer is given by yil and the average adoption is given by ATE $=E(y i)$. Thus, if we assume the binary variable $d$ to be an indicator for exposure and access to the improved varieties where $d 1$ denotes exposure and access to at least one improved variety and $d 0$, otherwise.

The estimation of adoption rates and its determinants can be done based on the observed random vectors $(y i, x i, d i, z i), i=1, \cdots, n$ from a sample of the population; where $x i$ is the vector of covariates that determines potential adoption outcome $(y i)$ and $z i$ is the vector of covariates that determine exposure and access $(d i)$ with $x i$ and $z i$ having common elements. An important assumption on which ATE in this study builds is the Conditional Independence Assumption that states that selection is solely based on observable characteristics and potential outcomes are independent of treatment assignment i.e. $p(y i=1 \mid d, z)$. Therefore ATE was estimated from a random sample of the population using pure parametric regression based-methods where covariates $x i$ interacted with treatment status variable. The parametric estimation of ATE is stated thus $\mathrm{ATE}=E(y / x, d=1)=f(x, \beta)$ where $f$ is a function of vector of covariates $x$ and the parameter vector $\beta$ which was determined using probit model with the observations $(y i, x i)$ from the subsample of exposed and access farmers only and $y$ being the dependent variable and $x$ the vector of explanatory variables. The marginal effects were estimated using ATE parametric model. With the estimated parameter $\beta$, the predicted values $f(x i, \beta)$ are computed for all the observations $i$ in the sample (both exposed and access farmers and non-exposed and non-access subsample) and ATE, ATE 1 and ATE0 are estimated by taking the average of the predicted $f(x i, \beta), i=1, \cdots, n$ across the full sample (for ATE) and respective subsamples (for ATE1 and ATE0).

$$
\begin{gathered}
\text { ATE }=\frac{1}{n} \sum_{i=1}^{n} f(x i, \beta) \\
\text { ATE } 1=\frac{1}{n e} \sum_{i=1}^{n} \operatorname{dif}(x i, \beta) \\
\text { ATE } 0=\frac{1}{n-n e} \sum_{i=1}^{n}(1-d i) f(x i, \beta)
\end{gathered}
$$

The population adoption gap becomes (GAP = JEA - ATE1), and the population selection bias becomes (PSB = ATE1 - ATE) parameters using the parametric regression based estimators above. ATE is the population mean adoption outcome when all members of the population have been exposed and have access to improved varieties, the mean adoption outcome in the exposed and 
access subpopulation is the average treatment effect on the treated denoted as ATE1 or ATT [8]. The difference between the population mean adoption outcome (ATE) and the mean adoption outcome among the exposed and have access (ATE1) is the population selection bias (PSB). The joint exposure adoption rate (JEA), measures the likely adoption rate if all respondents are exposed and have access to the improved groundnut varieties. The adoption gap (GAP) measures the difference between potential adoption rate among the exposed and access (ATE1).

\section{Materials and Methods}

The study was conducted in Bauchi, Jigawa, Kano, Katsina and Kebbi States in North West Nigeria at the end of the rain-fed cropping season in 2017. These States lies essentially in the Northern Guinea and Sudan Savanna ecologies of Nigeria (Figure 1). In each of the state, improved groundnut varieties have been promoted using the Agricultural and Rural Development Authorities, which serves as the extension arms of their various State Ministries of Agriculture to provide farm advisory services to the farmers under the unified agricultural extension system called "Research, Extension, farmer, Input, Linkage System" (REFILS).

In each State, three LGAs where purposively selected based on extensive cultivation of groundnut by the people. In each of the LGAs, $2-3$ communities where again, groundnut was extensively cultivated and where at least, on-farm groundnut demonstration, seed production system, groundnut up-scaling or participatory variety selection (PVS) must have been held within the TL Project circles. One hundred (100) farmers spread across the selected communities in each LGA were randomly selected from among groundnut farmer groups assembled by their associations/cooperatives in the selected communities at central locations such as the community square, school or District/Ward Head compounds. From each farmer or household head interviewed, socio-economic, production, assets and market data as well as samples of the groundnut variety ( 2 - 3 nuts) cultivated were collected, put in a seed sample envelope and properly labeled using the same household Identification (ID) as the questionnaire for the purpose of finger printing analysis. The primary data were collected using electronic data capturing instrument containing the questionnaire. The enumerators were recruited based on their ability to use Android phones, past experience with such data collection method and then trained on the use of electronic data capturing using the set supplied by the team or use of their own phones. In all, a total of 1476 households were interviewed while groundnut samples were collected from 1459 households for finger printing analysis (Table 1). It could be observed that the groundnut samples collected were less than the number of households sampled and this was because of improper labeling of sample envelops by some enumerators that lead to rejection of some samples. The data collected were analyzed with descriptive statistics and Average Treatment Effect 
Table 1. Distribution of households sampled and groundnut variety samples collected according to state and local government areas (LGAs) from the project states.

\begin{tabular}{|c|c|c|}
\hline State/LGA & Household surveyed & Samples collected \\
\hline Bauchi & 300 & 295 \\
\hline Ningi & 100 & 97 \\
\hline Shira & 101 & 100 \\
\hline Tafawa Balewa & 99 & 98 \\
\hline Jigawa & 301 & 297 \\
\hline Gumel & 100 & 100 \\
\hline Kiyawa & 101 & 100 \\
\hline Taura & 100 & 97 \\
\hline Kano & 301 & 300 \\
\hline Bichi & 101 & 100 \\
\hline Dawakin Tofa & 100 & 100 \\
\hline Kunchi & 100 & 100 \\
\hline Katsina & 300 & 300 \\
\hline Dutsinma & 100 & 100 \\
\hline Jibia & 100 & 100 \\
\hline Mashi & 100 & 100 \\
\hline Kebbi & 274 & 267 \\
\hline Aliero & 79 & 77 \\
\hline Dandi & 97 & 97 \\
\hline Maiyama & 98 & 93 \\
\hline Total & 1476 & 1459 \\
\hline
\end{tabular}

(ATE) framework.

\section{Results and Discussion}

\subsection{Socio-Economic and Farm Characteristics}

\subsubsection{Household Characteristics}

The various characteristics of the household heads in the study area are depicted in Table 2 and described below. The result of the analysis in Table 2 revealed that the mean age of household heads varies from 42 in Bauchi State to 48 years in Kebbi State with a mean of 45 years for the study States and are statistically different from one state to another at $1 \%$ level of probability. The result suggests that the groundnut farmers are in their middle ages and strong enough to accomplish the numerous tasks involving drudgery of production and this finding is in line with the work of Ajeigbe [7]. The result in Table 2 further shows that average sex of the households varies from $89 \%$ in Bauchi State to $98 \%$ in Kano being male-headed, but with a mean of $92 \%$ across the States, suggesting 
Table 2. Households socio-economic and farm characteristics according to states.

\begin{tabular}{|c|c|c|c|c|c|c|c|}
\hline variables & $\begin{array}{c}\text { Bauchi } \\
(n=301)\end{array}$ & $\begin{array}{c}\text { Jigawa } \\
(\mathrm{n}=295)\end{array}$ & $\begin{array}{c}\text { Kano } \\
(n=300)\end{array}$ & $\begin{array}{c}\text { Katsina } \\
(n=300)\end{array}$ & $\begin{array}{c}\text { Kebbi } \\
(n=274)\end{array}$ & $\begin{array}{c}\text { Pooled } \\
(n=1470)\end{array}$ & $\begin{array}{c}\text { Test of } \\
\text { comparison }\end{array}$ \\
\hline Age (years) & $41.8(13)$ & $45.9(11.4)$ & $45.4(12.4)$ & $45.8(11.5)$ & $48(10.4)$ & $45.3(11.9)$ & $10.52^{\star * \star}$ \\
\hline Sex $($ male $=1)$ & 0.89 & 0.84 & 0.98 & 0.92 & 0.97 & 0.92 & $57031^{\star * *}$ \\
\hline Education (number of years) & $6.3(6.3)$ & $1.2(3.6)$ & $2.5(4.8)$ & $2.6(5.1)$ & $2.1(4.7)$ & $2.9(5.3)$ & $45.05^{* * *}$ \\
\hline Married $($ yes $=1$ ) & 0.88 & 0.98 & 0.97 & 0.98 & 0.99 & 0.96 & $7189^{* * *}$ \\
\hline Main activity (agriculture $=1$ ) & 0.73 & 0.96 & 0.79 & 0.84 & 0.94 & 0.85 & $85.43^{* * *}$ \\
\hline $\begin{array}{l}\text { Participation in farm activities } \\
\quad(\text { full-time worker }=1)\end{array}$ & 0.42 & 0.96 & 0.81 & 0.79 & 0.95 & 0.78 & $333.64^{* * *}$ \\
\hline Household size (number of persons) & $8.9(6.8)$ & $9.4(6.4)$ & $9.1(6.1)$ & $10.3(6.4)$ & $9.6(7.2)$ & $9.4(6.6)$ & $2.01^{*}$ \\
\hline Experience (years) & 16.8. (13.3) & $23.6(11.8)$ & $24.6(13.6)$ & $20.6(11.2)$ & $25.5(13.6)$ & $22.2(13.1)$ & $23.07^{\star * *}$ \\
\hline $\begin{array}{l}\text { Contact with agricultural advisors } \\
\text { (number of visits) }\end{array}$ & $0.9(1.8)$ & $3.8(3.2)$ & $6.6(8.6)$ & $3.6(5.4)$ & $5.9(12.9)$ & $4.1(7.7)$ & $27.11^{\star * *}$ \\
\hline $\begin{array}{l}\text { Involved in technology transfer activity } \\
\qquad(\text { yes }=1)\end{array}$ & 0.15 & 0.60 & 0.31 & 0.20 & 0.44 & 0.34 & $174.52^{* * *}$ \\
\hline $\begin{array}{l}\text { Participation in agricultural training } \\
\qquad(\text { yes }=1)\end{array}$ & 0.11 & 0.24 & 0.37 & 0.15 & 0.18 & 0.21 & $77.92^{\star * *}$ \\
\hline Living in TLIII village (yes $=1$ ) & 0.44 & 0.84 & 0.40 & 0.80 & 0.79 & 0.65 & $242.72^{\star * *}$ \\
\hline Distance to market $(\mathrm{km})$ & $7.1(7.6)$ & $16.9(24.9)$ & $5.2(5.1)$ & $5.3(5.7)$ & $11.6(18.3)$ & $9.14(15.3)$ & $34.91^{* * *}$ \\
\hline Groundnut area (ha) & $1.98(1.68)$ & $1.83(1.63)$ & $1.04(1.02)$ & $1.88(1.45)$ & $2.99(2.36)$ & $1.94(1.79)$ & $42.67^{* * *}$ \\
\hline Yield (kg/ha) & $587.11(427.62)$ & $\begin{array}{c}521.11 \\
(403.47)\end{array}$ & $\begin{array}{c}825.77 \\
(567.62)\end{array}$ & $\begin{array}{c}683.48 \\
(531.53)\end{array}$ & $\begin{array}{c}943.66 \\
(597.06)\end{array}$ & $\begin{array}{c}709.44 \\
(532.78)\end{array}$ & $30.10^{\star * \star}$ \\
\hline Seed quantity (kg/ha) & $17.44(10.81)$ & $19.38(14.34)$ & $26.83(16.40)$ & $19.58(13.01)$ & $19.99(10.53)$ & $20.62(13.56)$ & $16.88^{\star * *}$ \\
\hline Crops mixture $($ yes $=1$ ) & 0.39 & 0.70 & 0.83 & 0.62 & 0.33 & 0.58 & $184.68^{\star * *}$ \\
\hline Crops rotation $($ yes $=1$ ) & 0.27 & 0.55 & 0.80 & 0.50 & 0.20 & 0.47 & $232.21^{\star \star *}$ \\
\hline
\end{tabular}

a Pearson $\mathrm{Chi}^{2}$ test for qualitative variables and Fisher F (ANOVA) test for quantitative variables; ${ }^{* *}$ significant at $1 \%$; ${ }^{* *}$ significant at $5 \%$; ${ }^{*}$ significant at $10 \%$.

that male headed households dominated the groundnut producing households in Nigeria. This is quite expected especially given the tradition and culture of the people in the study States that makes male head of household and, only in rare cases of death of a husband and his brothers, and in advanced age of the widow that a female becomes a household head. The level of awareness and adoption of agricultural innovations are affected by the literacy status of farmers, therefore education plays an important role in the adoption of an innovation. From the result, Jigawa spent the least number of years (1.2) in school while Bauchi has the highest of 6.3 years, which is an indication that Bauchi State has the most literate number of farmers in the Project States. The average level of literacy across the States is 2.9 years in school (about three years in primary school), an indication that literacy level in the project states is very low and this can hinder full adoption of agricultural innovations by farmers. Marital status (married $=1$ ) shows that it varies from $88 \%$ in Bauchi to $99 \%$ in Kebbi State indicating that 
almost all household heads were married in the project states and those not married may be widowers or are in advanced age. The mean marital status was $96 \%$, an indication that about $4 \%$ were not married.

Agriculture as main occupation varies from State to State with Bauchi State having the least of $73 \%$ and Jigawa the highest of $96 \%$. The average across States was $85 \%$ which means that about $85 \%$ of the household heads practiced agriculture as an occupation. Also, agriculture as full-time work revealed that agriculture is practiced at different levels of involvement by the household heads. In the study States, Bauchi State has the least level of engagement in agriculture at $42 \%$ full-time employment and the highest was Jigawa at $96 \%$ full employment. The average across the states was $78 \%$ full time engagement. The result of the analysis in Table 2 revealed that the average household size ranges from 9 persons in Bauchi to 10 in Katsina States and a mean of 9 for all the States studied. Pair test comparison of the household size by state shows it was only significant at $10 \%$ level of probability. This shows that the household size is large in the study areas and this implies that family labour for farm operations may not be a problem. Groundnut farming experience varies from 16.8 years in Bauchi State to 25.5 years in Kebbi State while the mean for all the States is 22.3 years. The result is an indication that the farmers have been into groundnut production over a long term and must have cultivated one or more of the improved varieties over time.

Contacts with farm advisory service providers have always been a means of creating awareness on new improved farm technologies and therefore setting the stage for farm technology adoption among farming households. In this study, Bauchi had the least number of contacts of 1 while Kano State had the highest of 7 contacts per year but with the average of 4 contacts for all States. Thus, except for Bauchi State, farm advisory service was readily available in the project States and Kano State topped them because, they had higher extension agent: farmer ratio, especially following their recent large recruitment of extension staff and deploying them to the field. Involvement in technology transfer activity of the household heads measured as yes or no shows that the level was low and ranges from $15 \%$ in Bauchi state to $60 \%$ in Jigawa state with a mean of $34 \%$ for all the states. Thus, farmers in Jigawa State were more exposed to groundnut technology transfer activities than other States and probably be expected to have higher level of awareness and adoption.

Participation in agricultural training is a mean for enhancing adoption. In this study, the level of participation in agricultural training was low and ranging from $11 \%$ in Bauchi State to $37 \%$ in Kano state while the mean for all the states is $21 \%$, an indication that most of the households have never attended any agricultural training activity, which is a measure of poor extension activities across the states and this may be as a result of neglect of the Visits and Training (V \& $\mathrm{T}$ ) extension system that has been in practice in Nigeria. In that system, there is a forth nightly training for farmers by Subject Matter Specialist (SMS) following the Monthly Technology Review Meeting (MTRM) in the ADPS. The V \& T 
system of extension has virtually collapsed in Nigeria due to lack of funding of the ADPs by the various State governments, especially since the coming of civilian administration.

Farmers living in TL III villages in the project States varies from $40 \%$ in Kano state to $84 \%$ in Jigawa State but the mean for all states is $65 \%$, which means that as many as $35 \%$ of the household survey lived outside TL III project sites and the farmers may not have been completely exposed to the newly released varieties promoted through the TL III Project. Distance of farm households to markets shows Kano State has the least distance to markets of $5.2 \mathrm{~km}$ while Jigawa has the longest of $16.9 \mathrm{~km}$, but the average distance for the states is $9.14 \mathrm{~km}$, which suggest that farmers must incur transportation cost to buy inputs and to sell off their produce. This invariably affects the final market prices of the produce in all the states.

\subsubsection{Farm Characteristics}

The result in Table 2 shows that the average area of land cultivated to groundnut was least at 1.04 ha in Kano state and highest in Kebbi state at 2.99 ha while the average for the entire states is $1.94 \mathrm{ha}$. This result shows that production is by small scale farmers as stated by Federal Ministry of Agriculture and Rural Development (FMARD) [9] that there is high variability in area cultivated. The average groundnut yield was lowest in Jigawa State at $521.11 \mathrm{~kg} / \mathrm{ha}$ and highest in Kebbi State at $943.66 \mathrm{~kg} / \mathrm{ha}$ while the mean across the states was $709.44 \mathrm{~kg} / \mathrm{ha}$. The variability in yield is attributed to rainfall pattern and the level of inputs used by farmers. In 2017 cropping season, early and late drought was reported in many of the states particularly in Jigawa and Bauchi states which led to the poor yields in some states to the extent that in some cases, only haulm was harvested. The average seed use ranged from $17.44 \mathrm{~kg} / \mathrm{ha}$ in Bauchi state to the highest usage of $26.83 \mathrm{~kg} / \mathrm{ha}$ in Kano state while the average across the states is 20.62 $\mathrm{kg} / \mathrm{ha}$. The seed rate determines the plant population and hence the yield ceteris paribus, thus those using close to recommended rate of about $60 \mathrm{~kg} / \mathrm{ha}$ may perform better in terms of yield.

The result in Table 2 further revealed that groundnut is produced under sole cropping and in crop mixtures of different patterns. In the study areas, farmers in all states produced groundnut as crop mixtures with Kebbi state having the least population of $33 \%$ and Kano state the highest population of $83 \%$ while across the project states, the mean is $58 \%$, meaning that while about 58 percent of farmers produced groundnut under crop mixtures, 42 percent produce under sole cropping. This has implication for yield as sole cropping yield higher than under crop mixtures but because farmers in these states consider the risk of crop failures under sole cropping, they preferred the option of low yield under crop mixtures to a complete crop failure under sole cropping. The practice of crop rotation was least (27\%) practiced in Kebbi state but highest (80\%) in Kano state while the mean in all states is $47 \%$. This means that more education of farmers 
on crop rotation is needed to enhance soil fertility for higher yield, especially with present high cost of fertilizers.

Knowledge, Access and Adoption of improved groundnut varieties across States

The result of the analysis in Table 3 shows that there is $100 \%$ level of awareness among the groundnut farmers in all the states of improved groundnut varieties. However, the level of access to the improved varieties varies from $96.53 \%$ in Kebbi State to $100 \%$ in Katsina States while the mean access rate across project States was $97.97 \%$ and was statistically different at 5 percent level of significance. It should be noted that the awareness of these varieties is not restricted to only the varieties promoted by Tropical Legume Project but covers all earlier released varieties. However, in recent times, the TL III Project has done greatly in creating awareness and providing access to the recently released improved groundnut variety seeds (Samnut 24, Samnut 25 and Samnut 26) through its various programmes.

The result in Table 3 further revealed that the level of utilization (home usage) of the improved varieties in 2017cropping season was lowest in Kebbi State at $18.68 \%$ and highest at $55.44 \%$ in Jigawa state while the mean for all the States was $43.63 \%$. The difference in utilization level was statistically significant at 1 percent level of probability. The low level of utilization in Kebbi State may be due to the fact that the state only joined TL III project in year 2015 cropping season through the TL III seed system and USAID groundnut up-scaling projects.

\subsection{Adoption Rates}

The result of the adoption analysis is presented in Table 4. In order to determine the adoption rate, it is confirmed from Table 3 that farmers were in full awareness and have quasi-full access and therefore to adopt, a farmer must have tested at least one improved variety before 2017 production season. The potential adoption rate (ATE) among the female producers was $70 \%$ while among the males it was $53 \%$ while among the pooled data; it was $54 \%$ and was statistically significant at 1 percent level of probability. For the farmers that were exposed to improved varieties, adoption rate (ATE1) among the females was $72 \%$ while among the males, it was $56 \%$ but the mean across states was $44 \%$ and were statistically different from one another. On the other hand, for the unexposed farmers, the adoption rate (ATE0) among the females was 59\% while among the

Table 3. Knowledge, access and adoption according to states.

\begin{tabular}{cccccccc}
\hline & Bauchi & Jigawa & Kano & Katsina & Kebbi & Pooled & $\begin{array}{c}\text { Test of } \\
\text { Comparison }\end{array}$ \\
\hline Awareness (\%) & 100 & 100 & 100 & 100 & 100 & 100 & -- \\
Access (\%) & 96.80 & 98.58 & 97.39 & 100 & 96.53 & 97.97 & $9.31^{\star *}$ \\
Utilization in 2017 (\%) & 44.30 & 55.44 & 42.35 & 55.23 & 18.68 & 43.63 & $96.60^{* * *}$ \\
\hline
\end{tabular}

NB. ${ }^{* *}$ Statistically significant at $1 \%$ level of probability, ${ }^{* *}$ statistically significant at $5 \%$ level of probability. 
Table 4. Adoption rates among groundnut farmers.

\begin{tabular}{cccc}
\hline & Female & Male & Pooled \\
\hline Potential adoption rates & & & \\
ATE & $0.70^{* * *}(0.04)$ & $0.53^{* * *}(0.01)$ & $0.54^{* * *}(0.01)$ \\
ATE1 & $0.72^{* * *}(0.04)$ & $0.56^{* * *}(0.01)$ & $0.57^{* * *}(0.01)$ \\
ATE0 & $0.59^{* * *}(0.05)$ & $0.43^{* * *}(0.02)$ & $0.44^{* * *}(0.02)$ \\
JEA & $0.61^{* * *}(0.03)$ & $0.43^{* * *}(0.01)$ & $0.44^{* * *}(0.01)$ \\
GAP & $-0.09^{* * *}(0.01)$ & $-0.10^{* * *}(0.00)$ & $-0.10^{* * *}(0.00)$ \\
Observed adoption rates & & & \\
PSB & $0.02^{* * *}(0.00)$ & $0.03^{* * *}(0.00)$ & $0.03^{* * *}(0.00)$ \\
Ne/N & $0.84^{* * *}(0.03)$ & $0.77^{* * *}(0.01)$ & $0.77^{* * *}(0.01)$ \\
Na/N & $0.60^{* * *}(0.05)$ & $0.42^{* * *}(0.01)$ & $\left.0.44^{* * *} 0.01\right)$ \\
$\mathrm{Na} / \mathrm{Ne}$ & $0.71^{* * *}(0.06)$ & $0.56^{* * *}(0.02)$ & $0.57^{* * *}(0.02)$ \\
\hline
\end{tabular}

Note: Robust standard error in parenthesis. ${ }^{* *}$ Statistically significant at $1 \%$ level of probability. $\mathrm{Ne} / \mathrm{N}=$ exposure rate, $\mathrm{Na} / \mathrm{N}=$ observed adoption rate for entire population. $\mathrm{Na} / \mathrm{Ne}=$ Observed adoption rate among exposed population.

males, it was $43 \%$ but the pooled data was $44 \%$ and the results were statistically significant at 1 percent, this finding can be compared with the work of Kassie, Shiferaw and Muricho [10]. As was seen from participation in groundnut technology transfer activities and training, females were more involved than males; hence they have higher adoption rates than their male counterparts.

The joint exposure adoption rate (JEA), which measures the likely adoption rate if all respondents are exposed to the improved groundnut varieties, show that adoption rate will be $61 \%$ for females and $43 \%$ for males while the mean for the pooled data will be $44 \%$. The adoption gap (GAP) which measures the difference between potential adoption rate among the exposed (ATE1) and the potential adoption rate (ATE) for the entire population is $9 \%$ for females and 10 percent for males while the mean is also $10 \%$ for the pooled data. It means that if all respondents are exposed to improved varieties, the potential adoption rate will increase by about $10 \%$ from the current level, hence the coefficient was negative. These findings can be compared with the findings of Simtowe [11]. The population selection bias (PSB) for female is $2 \%$ while for the male is $3 \%$ and the mean for entire population is $3 \%$. The parameter was statistically different from zero at 1 percent level of probability, which is an indication of the acceptance of the null hypothesis that the unexposed subpopulation is equally likely to adopt the improved groundnut varieties. The exposure rate from the population $(\mathrm{Ne} / \mathrm{N})$ is $84 \%$ for female, $77 \%$ for males and $77 \%$ for the pooled data and with all the parameters being statistically different from zero at 1 percent level of probability. On the other hand, observed adoption rate without accounting for the exposed $(\mathrm{Na} / \mathrm{Ne})$ was $60 \%$ for females, $42 \%$ for males and $44 \%$ for the pooled data with all parameters being statistically different from zero at $1 \%$ level of sig- 
nificance. Also, the observed adoption rate among the exposed subpopulation was $71 \%$ for female, $56 \%$ for males and $57 \%$ for the entire population. However, according to Diagne and Demont [7], ATE, which measures the effect or impact of treated on the person randomly selected from the population represent the unbiased adoption rate and in this case, it was $54 \%$. All the parameters were statistically significant at $1 \%$ level of significance.

The result from DNA finger printing analysis tend to corroborate this finding as the result showed that $58.21 \%$ of the 1535 groundnut producing households samples collected were from improved varieties [12]. The difference was attributable to the fact that about $7 \%$ of the households could only identify varieties by their local names and these were unknown to breeders and seeds specialists. The finger printing result further showed that SAMNUT 24 was the highest variety of importance, as it accounted for $26 \%$ of area cultivated in 2017 cropping season [12].

\section{Conclusion}

The breeding and promotion of improved groundnut varieties in Nigeria through the efforts of IAR and ICRISAT and supported by Tropical Legume Project, and with the synergy of USAID groundnut upscaling project in Nigeria resulted in very high level of awareness of improved varieties, more than average level of access to the improved variety seeds and moderate level of utilization of the improved varieties among the groundnut farmers. The adoption rate of improved varieties increased significantly from $8 \%$ at based line to $57 \%$, while the DNA fingerprinting results revealed that as much as $58.2 \%$ of the groundnut varieties cultivated was improved. The study recommends support for extension of Tropical Legume Project activities and/ or taking ownership of the Project activities by States ADPs to enhance more access to and adoption of the improved groundnut varieties by the farmers in the country.

\section{Acknowledgements}

The authors acknowledge the financial support from Bill and Melinda Gates Foundation for TL III Project in Nigeria, the State's Agricultural and Rural Development Authorities management and staff for their support for data collection and all the farmers from whom data were collected for their time and cooperation. The support of the management of IAR in the project is highly acknowledged.

\section{Conflicts of Interest}

The authors declare no conflicts of interest regarding the publication of this paper.

\section{References}

[1] Sogut., T., Ozturk, F. and Kizil, S. (2016) Effect of Sowing Time on Peanut (Arachis Hypogaea L.) Cultivars: II. Fatty Acid Composition. Agriculture and Agricultural 
Science Procedia, 10, 76-82. https://doi.org/10.1016/j.aaspro.2016.09.018

[2] Ajeigbe, H.A., Waliyar, F., Echekwu, C.A., Ayuba, K., Motagi, B.N., Eniayeju, D. and Inuwa, A. (2014) A Farmer's Guide to Groundnut Production in Nigeria. ICRISAT, Kano.

[3] CGIAR (2004-2005) Research \& Impact: Areas of Research: Groundnut. http://www.cgiar.org/impact/research/groundnut.html. CGIAR 2004-2005.

[4] Pazderka, C. and Emmott, A. (2010) Chatham House Procurement for Development Forum: Groundnut Case Study Report, 1-15.

[5] Ndjeunga, J. and Ibro, A. (2010) Groundnut Trends and Prospects in West and Central Africa. A Report of International Crops Research Institute for the Semi-Arid Tropics (ICRISAT). Unpublished Paper.

[6] Bill and Melinda Gates Foundation (2019) Report of Tropical Legume III-Improving Livelihoods of Smallholder Farmers: Enhance Grain Legume Productivity and Production in Sub-Saharan Africa and South Asia. Final Report, ICRISAT, Hyderabad, India.

[7] Diagne, A. and Demont, M. (2007) Taking a New look at Empirical Models of Adoption: Average Treatment Effect Estimation of Adoption Rate and Its Determinants. Agricultural Economics, 37, 30.

https://doi.org/10.1111/j.1574-0862.2007.00266.x

[8] Wooldrige, J. (2002) Econometric Analysis of Cross Section and Panel Data. The MIT Press, Cambridge, Massachusetts, USA.

[9] Federal Ministry of Agriculture and Rural Development (FMARD) (2010) National Agriculture and Food Security Strategy, 2010-2020. Abuja, Nigeria, 25 August 2010.

[10] Kassie, M., Shiferaw, B. and Muricho, G. (2010) Adoption and Impact of Improved Groundnut Varieties on Rural Poverty. Evidence from Rural Uganda. A Report, Environment for Development (EfD DP 10-11). Discussion Paper.

[11] Simtowe, F. (2011) Determinants of Agricultural Technology Adoption: the Case of Improved Pigeon pea Varieties in Tanzania. MPRA Working Paper, 1-22.

[12] Melesse, M.B. and Hasuer, M. (2019) Genetic Fingerprinting Analysis to Track the Adoption of Improved Groundnut and Chickpea Varieties in Nigeria, Tanzania and Ethiopia. Report Presented at the Tropical Legumes III, End of Project Workshop, Mount Meru Hotel, Arusha, Tanzania, 16-81 July 2019. 